\title{
Determination of an optimal isolation and culture conditions of grass pea protoplasts
}

\author{
Barbara Piwowarczyk, AnNa Pindel \\ Department of Biotechnology and Horticulture, Institute of Plant Biology and Biotechnology \\ University of Agriculture in Cracow, Kraków, Poland \\ Corresponding author: b.piwowarczyk@ogr.ur.krakow.pl
}

\begin{abstract}
This paper presents a study on determination of optimal grass pea (Lathyrus sativus L.) protoplast isolation and culture conditions. The plant material comprised the Polish variety "Derek". Explants for protoplast isolation were leaves of 10, 15, 21 and 28 day-old in vitro and in vivo grown seedlings. The plant material was briefly incubated (3-4 hours) or left overnight (17-18 hours) in different enzymatic mixtures. The isolation efficiency and viability of protoplasts were assessed to compare the applied isolation conditions. The best selected isolation conditions were used in subsequent experiments. Protoplast cultures were established in liquid and solid media enriched in various supplements. Protoplast viability, morphological responses and cell wall reconstruction were evaluated. Grass pea leaves proved to be a good source of protoplasts. The origin and the age of donor plants as well as the type of the applied enzymatic mixture had an impact on the isolation efficiency, viability of protoplasts and further protoplast responses during the culture. Overnight incubation resulted in a higher yield of protoplasts. However, protoplasts isolated from briefly incubated material had higher viability. Protoplasts from leaves of 15-21 day-old in vitro seedlings obtained after overnight isolation showed the highest viability on the 10th day of cultivation. In liquid media, protoplasts survived for about 10 days and only an addition of chitosan prolonged their viability to more than 15 days. Shape changes and intensive budding of protoplasts were observed during the culture. Although no steady mitotic activity was observed in liquid media, occasional cell divisions were noted in an agarose-droplet culture. After 24 hours, grass pea mesophyll protoplasts rebuilt their cell wall at different ratios (10-60\%) depending on the applied media. A high frequency of protoplast budding suggests some abnormalities in cell wall structure that prevent the further development of a culture.
\end{abstract}

Key words: agarose-droplet culture, chitosan, Lathyrus sativus, leaf mesophyll, protoplast isolation efficiency, protoplast viability

\section{Introduction}

The significance of grass pea (Lathyrus sativus L.), a grain-leguminous plant, in agriculture is constantly growing. The high protein content in the seeds, together with resistance to drought and tolerance to diseases and pests, make grass pea an outstanding, alternative source of protein. Additionally, grass pea plants grow and develop on poor soils and in harsh environmental conditions, in contrast to other high-protein legume crops (Campbell et al., 1994; Vaz Patto et al., 2006). However, despite the efforts of plant breeders, grass pea has a number of disadvantages, e.g. pod shattering, prostrate plant habit, late maturity, indeterminate growth, and anti-nutritional substances in seeds (Rybiński, 2003). All these features limit the spread of grass pea cultivation.
The improvement of the species is associated with the necessity of receiving new genotypes. Interspecific crossbreeding within the Lathyrus genus is difficult and, unfortunately, the reasons for this incompatibility are not known (Campbell, 1997). A problem is also the lack of some desirable traits in the available breeding materials. Consequently, conventional breeding based on recombination is not very effective. This forces the search for alternative methods of breeding. Besides mutation breeding, in vitro methods also enable the possible extension of the genetic variation of this species. Protoplast cultures enable new recombinants to be obtained by protoplast fusion and somatic hybridization. This is particularly important in the case of crossing barriers between parental components. Furthermore, the fusion 
of grass pea protoplasts with pea protoplasts is desirable, because of the resistance of grass pea to Ascochyta blight (Campbell, 1997; Duriou and Ochatt, 2000). Owing to the absence of the cell wall, protoplasts are also excellent explants for genetic transformation. Notwithstanding this factor, efficient protoplast isolation and culture, as well as plant regeneration protocols, are indispensable to use all these techniques.

Although some protocols for plant regeneration from protoplast cultures have been developed for several grain legume crops (Ochatt et al., 2000; Dhir et al., 1992; Tegeder et al., 1995), there have been no reports on plant regeneration from protoplast cultures of the Lathyrus species. The first isolation of grass pea protoplasts was carried out by McCutchan from shoots and a cell suspension in 1999 (McCutchan, 2001). However, the obtained protoplasts did not exhibit the ability to divide. Durieu and Ochatt (2000) isolated protoplasts from embryonic axis shoots that subsequently divided and formed microcalli. Until now this has been the only report on dividing grass pea protoplasts.

The aim of this study was to develop optimal conditions for grass pea protoplast isolation and culture.

\section{Materials and methods}

\section{Plant materials}

The plant material was a Polish variety of grass pea: "Derek". The seeds were obtained from Professor Wojciech Rybiński at the Institute of Plant Genetics of the Polish Academy of Sciences (Poznań, Poland). Explants for protoplast isolation came from in vitro and in vivo grown seedlings. To obtain seedlings in vitro, seeds were surface sterilized for $60 \mathrm{~s}$ in $70 \%$ ethanol, $25 \mathrm{~min}$ in $0.1 \% \mathrm{HgCl}_{2}$ and then rinsed five times in sterile distilled water. The seeds were placed on an agar solidified medium for seed germination composed of MS macro and microelements (Murashige and Skoog, 1962) with $20 \mathrm{~g} / \mathrm{l}$ sucrose. Sterile plant material was cultured at $25 \pm 1^{\circ} \mathrm{C}$ under a $16 / 8 \mathrm{~h}$ light photoperiod of $50 \mu \mathrm{mol} / \mathrm{m} / \mathrm{s}$ photosynthetic photon flux density. In order to obtain explants from plants in vivo, 6-8 seeds were sown to pots $(\varphi 12 \mathrm{~cm})$ containing universal soil and left in a greenhouse at approx. $18^{\circ} \mathrm{C}$. Collected explants (leaves) were sterilized as follows: $60 \mathrm{~s}$ immersion in $70 \%$ ethanol, 3 min immersion in $0.1 \% \mathrm{HgCl}_{2}$ and 5-rinses in sterile distilled water.

\section{Optimization of protoplast isolation}

Leaves from 10, 15, 21 and 28 day-old seedlings grown in vitro and in vivo were used as explants for protoplast isolation. Leaves with the lower epidermis removed were incubated in $10 \mathrm{ml}$ of an enzymatic mixture. Two enzymatic mixtures were used: EL I composed of 2\% Cellulase "Onozuka" R-10 (Kinki Yakult), 1\% Pectinase (Sigma) and EL II composed of 1\% Cellulase "Onozuka" R-10 (Kinki Yakult) and 0.5\% Macerozyme (Kinki Yakult). The enzymatic mixtures were prepared in a CPW solution (Frearson et al., 1973) with $0.1 \%$ MES [2-(N-morpholino) ethanesulfonic acid] buffer and 11\% (in vitro seedlings) and $12 \%$ (in vivo seedlings) sorbitol. In EL I solution, the material was incubated for 3-4 hours with shaking (100-120 rpm). In EL II solution, leaves were incubated overnight (17-18 hours), statically at $26 \pm 1^{\circ} \mathrm{C}$. Protoplasts were purified by filtration through a $100 \mu \mathrm{m}$ nylon-mesh filter and afterwards were rinsed three times with an appropriate sorbitol solution and twice with the respective culture medium.

\section{Assessment of the isolation conditions}

To evaluate the applied isolation conditions, the efficiency of protoplast isolation (the number of protoplasts per $1 \mathrm{~g}$ of fresh weight tissue) and protoplast viability (\%) directly after isolation were assessed. Protoplast viability was assessed by staining the protoplasts with an aqueous solution of $0.1 \%$ Evans Blue (Gaff and Okong'oOgola, 1971). Viable protoplasts remain colorless (the dye does not pass through the plasma membranes), while non-viable protoplasts are stained blue (the dye penetrates through the damaged membranes). These observations were conducted under a light microscope (Eclipse E400, Nikon). Additionally, protoplasts were suspended in liquid B1 medium and their viability was controlled during the subsequent days of culture. Those conditions of protoplast isolation that gave the longest viable protoplasts were used in further protoplast culture studies.

\section{Protoplast culture}

Protoplasts were cultivated in 12 different liquid media (Table 1 ). The density of the culture was $1 \times 10^{5}$ protoplasts $/ \mathrm{ml}$. They were then suspended in $2 \mathrm{ml}$ of a medium in Petri dishes ( $\varphi 40 \mathrm{~mm}$ ). The liquid medium of the composition favoring the longest survival protoplast rate was chosen to establish a solid protoplast culture 
Table 1. Composition of the media used for grass pea protoplast liquid culture

\begin{tabular}{|c|c|c|c|}
\hline $\begin{array}{l}\text { Medium } \\
\text { Code }\end{array}$ & $\begin{array}{l}\text { Mineral } \\
\text { salts and } \\
\text { vitamins }\end{array}$ & $\begin{array}{l}\text { Organic compounds } \\
\qquad[\mathrm{mg} / \mathrm{l}]\end{array}$ & $\begin{array}{l}\text { Growth regulators } \\
\qquad[\mathrm{mg} / \mathrm{l}]\end{array}$ \\
\hline $\mathrm{K} 1$ & $\mathrm{KM}^{\mathrm{a}}$ & $\begin{array}{l}250 \text { fructose, } 250 \text { ribose, } 250 \text { xylose, } 250 \text { mannose, } 40 \text { citric } \\
\text { acid, } 40 \text { fumaric acid, } 40 \text { malic acid, } 250 \text { casein hydrolyzate, } \\
250 \text { sucrose, } 60000 \text { glucose, } 20 \mathrm{ml} \text { coconut water }\end{array}$ & $\begin{array}{c}1.0 \text { NAA } \\
0.22,4-\mathrm{D} \\
0.5 \text { zeatin }^{\text {a }}\end{array}$ \\
\hline $\mathrm{K} 2$ & $\mathrm{KM}$ & $\begin{array}{l}\text { as in } \mathrm{K} 1,0.1 \mathrm{~L} \text {-tyrosine, } 0.1 \mathrm{~L} \text {-asparagine, } 0.1 \mathrm{~L} \text {-phenylalanine, } \\
0.1 \text { adenine, } 0.1 \mathrm{~L} \text {-serine, } 0.1 \mathrm{~L} \text {-proline, } 0.1 \mathrm{DL} \text {-tryptophan }\end{array}$ & as in $\mathrm{K} 1$ \\
\hline $\mathrm{B} 1$ & $\mathrm{~B}_{5}{ }^{\mathrm{b}}$ & 100 MES, 20 ascorbic acid, 10000 sucrose, 5000 glucose & $\begin{array}{l}0.5 \mathrm{NAA}, 0.52,4-\mathrm{D}, 0.52 \mathrm{iP} \\
0.5 \mathrm{BAP}, 0.5 \mathrm{GA}_{3}\end{array}$ \\
\hline $\mathrm{B} 2$ & $\mathrm{~B}_{5}$ & as in $\mathrm{B} 1$, amino acids as in $\mathrm{K} 2$ & as in $\mathrm{B} 1$ \\
\hline B3 & $\mathrm{B}_{5}$ & as inB1, 2.0 chitosan & as in $\mathrm{B} 1$ \\
\hline B4 & $\mathrm{B}_{5}$ & as inB1, 5.0 chitosan & as in B1 \\
\hline B5 & $\mathrm{B}_{5}$ & as inB1, 7.5 chitosan & as in B1 \\
\hline B6 & $\mathrm{B}_{5}$ & as inB1, 10.0 chitosan & as in $\mathrm{B} 1$ \\
\hline B7 & $\mathrm{B}_{5}$ & as inB1, 1000 Pluronic F-68 & as in B1 \\
\hline B8 & $\mathrm{B}_{5}$ & as inB1, 10000 Pluronic F-68 & as in B1 \\
\hline B9 & $\mathrm{B}_{5}$ & as inB1, 5.0 chitosan, 10000 Pluronic F-68 & as in B1 \\
\hline $\mathrm{B} 10$ & $\mathrm{~B}_{5}$ & as inB1, 50 acetylsalicylic acid & as in B1 \\
\hline $\mathrm{B} 11 *$ & $\mathrm{~B}_{5}$ & as in B4 & as in B1 \\
\hline $\mathrm{B} 12^{\#}$ & $\mathrm{~B}_{5}$ & as in B4 & as in $\mathrm{B} 1$ \\
\hline
\end{tabular}

a - according to Kao and Michayluk, 1975; b - according to Gamborg et al., 1968; * - sodium-alginate culture; \# - agarose-droplets culture

using agarose and sodium alginate. For the agarose-droplet culture, a protoplast suspension $\left(2 \times 10^{5}\right.$ protoplasts $/ \mathrm{ml}$ ) was mixed with an equal volume of a doublestrength medium with $1.6 \%(\mathrm{w} / \mathrm{v})$ Sea Plaque agarose (Cambrex Biosciences, Rockland, Maine, USA). The suspension was used to form 8 agarose droplets (each of $125 \mu \mathrm{l}$ volume) in one Petri dish. After solidification, the droplets were overlaid with $2 \mathrm{ml}$ of B4 liquid medium. For the sodium-alginate culture, the protoplast suspension $\left(2 \times 10^{5}\right.$ protoplasts $\left./ \mathrm{ml}\right)$ was mixed with an equal volume of $2.8 \%(\mathrm{w} / \mathrm{v})$ sodium alginate (Sigma-Aldrich Chemie, GmBH, Steinheim, Germany). A total volume of $200 \mu \mathrm{l}$ of the suspension was plated on the agar solidified $\mathrm{Ca}^{2+}$-medium to form thin alginate layers. After solidification, alginate layers were transferred to Petri dishes containing $2 \mathrm{ml}$ of $\mathrm{B} 4$ liquid medium. Cultures were incubated in the dark at $26 \pm 1^{\circ} \mathrm{C}$.

\section{Assessment of culture conditions}

The viability of protoplasts was evaluated on the isolation day, and then after 1, 5, 10 and 15 days of culture.
At those times, changes in protoplast morphology were also assessed. Protoplasts were categorized as spherical (protoplasts with their original shape), enlarged (more than twice the normal volume), budding (protoplasts with protuberances), oval (non-spherical, egg-shaped), snowmen-like (protoplasts with a narrowing in the equatorial part) and degenerating (darkened, collapsed protoplasts). Additionally, the rate of cellulosic cell wall reconstruction was estimated after 24 hours of culture. The regenerated cell walls of cultured protoplasts were stained with Calcofluor White (Sigma Chemical Co.) (Nagata and Takebe, 1970). A total volume of $100 \mu \mathrm{l}$ of the protoplast suspension was mixed with an equal amount of $0.01 \%$ aqueous dye solution. Protoplasts were stained for 5-10 minutes. After preparing specimens, protoplasts were viewed using a fluorescence microscope (AxioImager M2 multifunctional microscope, Zeiss) under UV light at a wavelength of $365 \mathrm{~nm}$. Photographic documentation was made using the AxioVision Rel. 4.8. program (Zeiss) and a PowerShot G10 camera (Canon). 


\section{Statistical analyses}

The experiment was performed in three replicates. In the isolation experiment, the replicate was each combination of isolation conditions was tested in replicate. In the culture experiment, the replicate was three Petri dishes of each medium. Protoplast viability, morphology changes and the wall reconstruction of the cell were expressed as percentages. At least 100 randomly chosen protoplasts were calculated in each count. The Post hoc LSD test was used to study differences between the means at $P=0.05$.

\section{Results}

\section{Protoplast isolation efficiency}

Protoplast isolation efficiency from leaves of in vitro grown grass pea seedlings was significantly higher using the EL II enzymatic mixture (Table 2). The age of in vitro grown seedlings did not significantly affect the number of released protoplasts (Table 2). However, considering together the donor material age and the type of enzymatic mixture, the highest protoplast isolation efficiency was observed from leaves of 21 and 28 day-old in vitro grown seedlings incubated in EL II solution (Table 2), whereas leaves from the oldest seedling incubated in EL I solution gave the smallest number of protoplasts. In the case of leaves collected from in vivo grown seedlings, there was no noticeable difference in isolation efficiency between the two applied enzymatic mixtures (Table 2). In contrast, the age of donor plants affected the number of released protoplasts. The highest yield of protoplasts was isolated from 15-day-old seedlings, and the lowest from 28-day-old ones (Table 2). The statistical analysis of these two influencing factors (enzyme mixture and seedling age) showed that most mesophyll protoplasts were obtained from the leaves that were harvested from 15 and 21 day-old in vivo grown seedlings, incubated in EL II enzyme mixture. The EL I mixture, containing a higher concentration of enzymes, was the most effective in terms of protoplast isolation from the youngest seedling leaves. Table 2 shows that a higher protoplast isolation efficiency was obtained using the in vivo leaves.

\section{Viability of freshly isolated protoplasts}

The viability of freshly isolated mesophyll protoplasts obtained from in vitro as well as in vivo grown plant material depended on the applied enzymatic mix- ture and was significantly higher after a short period of incubation in EL I solution (Table 2). The age of a donor plant had no impact on the viability of protoplasts isolated from in vitroleaves, regardless of the enzymatic mixture solution (Table 2). In contrast, in vivo leaves from the youngest and the oldest seedlings released the least viable protoplasts in EL II (Table 2). Taking into account only the origin of the material, there was no difference in the viability of protoplasts directly after isolation (Table 2).

\section{Viability of protoplasts in B1 medium}

Generally, the viability of protoplasts isolated from in vitro grown material declined significantly more slowly than in vivo protoplasts in the following days of culture (data not shown). Protoplasts from greenhouse seedlings degenerated regardless the type of enzyme applied and the age of the donor plant. In turn, in vitro protoplast viability noticeably decreased at a much slower pace after an overnight isolation in EL II enzyme, when leaves of 15 or 21 day-old seedlings were used as explants.

\section{Protoplast viability in the culture experiment}

In the whole experiment, the viability of freshly isolated protoplasts differed between each replication, so the survival rate of protoplasts was expressed as the percentage increase in the number of dead protoplasts in relation to initial viability. A completely lethal effect on the protoplasts was demonstrated by the addition of chitosan at a concentration above $7.5 \mathrm{mg} / \mathrm{l}$ (B5 and B6 media) and by a combination of chitosan and Pluronic F-68 (B9). On the second day after the culture was established, no viable protoplasts were observed in these media ( $\mathrm{Ta}$ ble 3). Very strong decline in the protoplast viability, after one-day cultivation, was also noted in $\mathrm{K} 1, \mathrm{~K} 2$ and B10 media (Table 3). After one-day cultivation, the greatest survival rate was noticed for protoplasts suspended in $\mathrm{B} 1$ medium and media enriched with lower concentrations of chitosan (B3, B4) and $10 \mathrm{~g} / 1$ Pluronic F-68 (B8) (Table 3). After 5 days of culture, the lowest decrease in protoplast viability was recorded in a B4 medium which contained $5 \mathrm{mg} / \mathrm{l}$ chitosan. At this length of cultivation, no viable protoplasts were observed in $\mathrm{K} 1, \mathrm{~K} 2$ or $\mathrm{B} 10$ media. Protoplasts immobilized in a sodium alginate film had the lowest rate of viability decline after 10 days of culture. However, among all the media tested, only in liquid B4 medium were viable protoplasts noted after 15 days of culture (Table 3). 
Table 2. Protoplast isolation efficiency (IE) and viability (V) depending on different factors

\begin{tabular}{|c|c|c|c|c|c|c|c|c|c|c|c|}
\hline \multicolumn{4}{|c|}{ Explant origin } & \multicolumn{4}{|c|}{ Enzymatic mixture } & \multicolumn{4}{|c|}{ Age of donor plant } \\
\hline & prot & $\begin{array}{l}\left(\times 10^{6}\right) \\
\text { asts /g f.w. }\end{array}$ & $\begin{array}{l}\mathrm{V} \\
(\%)\end{array}$ & & & $\begin{array}{l}6 \\
\text { g f.w. }\end{array}$ & $\begin{array}{l}\mathrm{V} \\
(\%)\end{array}$ & & $\begin{array}{r}\text { IE }\left(\times 10^{6}\right. \\
\text { protoplasts } / \xi\end{array}$ & & $\begin{array}{l}\mathrm{V} \\
(\%)\end{array}$ \\
\hline \multirow{4}{*}{ in vitro } & \multirow{4}{*}{\multicolumn{2}{|c|}{$4.8 \mathrm{~b}$}} & \multirow{4}{*}{$58 \mathrm{a}$} & \multirow{2}{*}{ ELI } & \multirow{2}{*}{\multicolumn{2}{|c|}{$3.5 \mathrm{~b}$}} & \multirow{2}{*}{$63 \mathrm{a}$} & 10 & $4.1 \mathrm{~b}$ & & 59 a \\
\hline & & & & & & & & 15 & $4.8 \mathrm{ab}$ & & 53 a \\
\hline & & & & \multirow{2}{*}{ ELII } & \multirow{2}{*}{\multicolumn{2}{|c|}{$6.2 \mathrm{a}$}} & \multirow{2}{*}{$51 \mathrm{~b}$} & 21 & $5.5 \mathrm{a}$ & & 55 a \\
\hline & & & & & & & & 28 & $4.2 \mathrm{~b}$ & & $68 \mathrm{a}$ \\
\hline \multirow{4}{*}{ in vivo } & \multirow{4}{*}{\multicolumn{2}{|c|}{$6.1 \mathrm{a}$}} & \multirow{4}{*}{$60 \mathrm{a}$} & \multirow{2}{*}{ ELI } & \multirow{2}{*}{\multicolumn{2}{|c|}{$5.0 \mathrm{a}$}} & \multirow{2}{*}{$81 \mathrm{a}$} & 10 & $4.6 \mathrm{bc}$ & & $60 \mathrm{ab}$ \\
\hline & & & & & & & & 15 & $8.0 \mathrm{a}$ & & $71 \mathrm{a}$ \\
\hline & & & & \multirow{2}{*}{ ELII } & \multirow{2}{*}{\multicolumn{2}{|c|}{$7.1 \mathrm{a}$}} & \multirow{2}{*}{$39 \mathrm{~b}$} & 21 & $6.9 \mathrm{ab}$ & & $64 \mathrm{a}$ \\
\hline & & & & & & & & 28 & $3.6 \mathrm{c}$ & & $36 \mathrm{~b}$ \\
\hline \multicolumn{6}{|c|}{ Origin/enzymatic mixture/age of donor plant } & \multicolumn{6}{|c|}{ Origin/enzymatic mixture/age of donor plant } \\
\hline \multicolumn{2}{|c|}{ in vitro } & \multicolumn{2}{|c|}{$\begin{array}{c}\text { IE }\left(\times 10^{6}\right) \\
\text { protoplasts /g f.w. }\end{array}$} & \multicolumn{2}{|c|}{$\begin{array}{c}\mathrm{V} \\
(\%)\end{array}$} & \multicolumn{2}{|c|}{ in vivo } & & $\begin{array}{l}\mathrm{E}\left(\times 10^{6}\right) \\
\text { plasts /g f.w. }\end{array}$ & & $\begin{array}{l}V \\
\%)\end{array}$ \\
\hline \multirow{4}{*}{ ELI } & 10 & 3.2 & & & $\mathrm{ab}$ & \multirow{4}{*}{ ELI } & 10 & & $7.6 \mathrm{bc}$ & & $5 \mathrm{ab}$ \\
\hline & 15 & $3.9 c$ & & & $\mathrm{bc}$ & & 15 & & $4.6 \mathrm{~cd}$ & & a \\
\hline & 21 & $4.3 \mathrm{c}$ & & & $\mathrm{abc}$ & & 21 & & $5.8 \mathrm{bcd}$ & & $a b$ \\
\hline & 28 & 2.2 & & & $7 \mathrm{a}$ & & 28 & & $3.6 \mathrm{~d}$ & & $\mathrm{abc}$ \\
\hline \multirow{4}{*}{ ELII } & 10 & 5.1 & & & $7 \mathrm{c}$ & \multirow{4}{*}{ ELII } & 10 & & $3.1 \mathrm{~d}$ & & $\mathrm{~cd}$ \\
\hline & 15 & 5.6 & & & $\mathrm{bc}$ & & 15 & & $11.5 \mathrm{a}$ & & $\mathrm{abc}$ \\
\hline & 21 & 6.8 & & & $\mathrm{bc}$ & & 21 & & $8.1 \mathrm{~b}$ & & $\mathrm{bc}$ \\
\hline & 28 & 8.3 & & & $a b c$ & & 28 & & $3.6 \mathrm{~d}$ & & $5 \mathrm{~d}$ \\
\hline
\end{tabular}

Means with the same letter are not significantly different; $g$ f.w. - g fresh weight

Table 3. Increase in protoplast death (\%) on subsequent days of culture in different media

\begin{tabular}{c|c|c|c|c}
\hline \multirow{2}{*}{ M } & \multicolumn{4}{|c}{ Day of culture } \\
\cline { 2 - 5 } & 1 & 5 & 10 & 15 \\
\hline K1 & $90.7 \mathrm{c}$ & $100.0 \mathrm{~h}$ & $100.0 \mathrm{~d}$ & $100.0 \mathrm{~b}$ \\
\hline B1 & $94.1 \mathrm{c}$ & $100.0 \mathrm{~h}$ & $100.0 \mathrm{~d}$ & $100.0 \mathrm{~b}$ \\
\hline B2 & $9.1 \mathrm{a}$ & $71.9 \mathrm{e}$ & $96.2 \mathrm{~cd}$ & $100.0 \mathrm{~b}$ \\
\hline B3 & $35.6 \mathrm{~b}$ & $89.7 \mathrm{~g}$ & $100.0 \mathrm{~d}$ & $100.0 \mathrm{~b}$ \\
\hline B4 & $8.3 \mathrm{a}$ & $31.7 \mathrm{~b}$ & $95.7 \mathrm{~cd}$ & $100.0 \mathrm{~b}$ \\
\hline B5 & $13.4 \mathrm{a}$ & $20.2 \mathrm{a}$ & $74.6 \mathrm{~b}$ & $92.9 \mathrm{a}$ \\
\hline B6 & $100.0 \mathrm{c}$ & $100.0 \mathrm{~h}$ & $100.0 \mathrm{~d}$ & $100.0 \mathrm{~b}$ \\
\hline B7 & $100.0 \mathrm{c}$ & $100.0 \mathrm{~h}$ & $100.0 \mathrm{~d}$ & $100.0 \mathrm{~b}$ \\
\hline B8 & $16.6 \mathrm{~b}$ & $81.2 \mathrm{f}$ & $97.7 \mathrm{~cd}$ & $100.0 \mathrm{~b}$ \\
\hline B9 & $100.0 \mathrm{c}$ & $100.0 \mathrm{~h}$ & $100.0 \mathrm{~d}$ & $100.0 \mathrm{~b}$ \\
\hline B10 & $94.9 \mathrm{c}$ & $100.0 \mathrm{~h}$ & $100.0 \mathrm{~d}$ & $100.0 \mathrm{~b}$ \\
\hline B11 & $14.7 \mathrm{a}$ & $44.7 \mathrm{c}$ & $64.0 \mathrm{a}$ & $100.0 \mathrm{~b}$ \\
\hline B12 & $7.0 \mathrm{a}$ & $51.9 \mathrm{~d}$ & $71.1 \mathrm{~b}$ & $100.0 \mathrm{~b}$ \\
\hline
\end{tabular}

Means (within one time of observation) with the same letter are not significantly different 


\section{Protoplast morphology changes}

Generally, after one day of culture no changes in the protoplasts shape were observed in the majority of media used. Only in media containing Pluronic-F68 were a small percentage of budding protoplasts observed (Table 4). The percentage of spherical protoplasts with regularly arranged bright-green chloroplasts varied depending on the media (Fig. 1B). Most spherical protoplasts (65.1\%) were noted in liquid B4 medium (Table 4). During the subsequent culture days, some changes in protoplast morphology (oval and snowmen-like protoplasts) were recorded, evidencing cell preparation to mitotic division (Fig. 1C and 1D). The majority of these protoplast types were observed after 5 days of cultivation in a liquid medium containing $5 \mathrm{mg} / \mathrm{l}$ chitosan and after 10 days in an agarose-droplet culture (8.2\%) (Table 4). Despite further control of the culture reactions, no steady, repeated mitotic activity of cells was recorded. Nevertheless, sporadic, single divisions were observed in the agarose-droplet culture (Fig. 1H and 1I), while protoplast "budding" occurred very often (Table 4, Fig. 1F). A common phenomenon was the occurrence of strongly enlarged protoplasts, with a diameter of 2-3 times greater than the average (Table 4, Fig. 1E). Changes in protoplast morphology mostly occurred in the first week of cultivation, and the addition of chitosan, apart from prolonging the viability of the protoplasts, stimulated protoplast budding relative to the $\mathrm{B} 1$ medium and addition of the Pluronic F-68 $(10 \mathrm{~g} / \mathrm{l})$ limited this process (Table 4).

\section{Protoplast cell wall reconstruction}

Grass pea protoplasts rebuilt their cell walls with different frequencies depending on the media composition (Fig. $1 \mathrm{G}$ and Fig. 2). After 24 hours, more than half (58-61\%) of cultivated protoplasts deposited cell walls in B1, B2, B3 and B4 media. In the media that do not favor the survival of protoplasts, the rate of cell wall regeneration was low (10-17\%). An addition of Pluronic F-68 to the media and embedding of protoplasts in solid media slowed down the process of cell wall reconstruction.

\section{Discussion}

The procedures of protoplast isolation, its culture and complete plant regeneration have been developed for many plant species (Davey et al., 2005). However, the protoplast culture technique, with its necessity of very precise treatments on fragile explants, is regarded as the most difficult of all in vitro methods (Lal and Lal, 2000). Additionally, legume plant species are considered to be very recalcitrant to in vitro conditions (Rybczyński, 2001). The present studies were undertaken to optimize the isolation conditions of grass pea "Derek" protoplasts and elaborate the initial stages of their further culture.

To a large extent, protoplast isolation efficiency is affected by the type of explant and the age and physiological condition of the donor plants (Babaoglu, 2000; Sinha et al., 2003). Mesophyll protoplasts are characterized by homogeneity and genetic stability (Blackhall et al., 1994) and have been successfully used to regenerate many plant species (Takebe et al., 1971; Shepard and Totten, 1977; Atanassov and Brown, 1984; Russell and McCown, 1988; Hu et al., 1999; Thomas, 2009; Castelblanque et al., 2010). In the present experiments, isolation from leaf mesophyll of grass pea seedlings gave a sufficient number of protoplasts suitable for further culture research. In isolation optimization procedures for other legumes, a clear correlation between the age of donor plant and isolation parameters have been demonstrated (Gill et al., 1987; Babaoglu, 2000; Sinha et al., 2003; Wiszniewska and Pindel, 2013). In the present experiment, the best result for the isolation parameter was achieved when leaves originating from 15 and 21 day-old seedlings were used.

In our study, enzymatic mixtures comprising the enzyme with cellulolytic ( $2 \%$ or $1 \%$ Cellulase "Onozuka" R10) and pectinolytic activity (1\% Pectinase or $0.5 \%$ Mecerozyme) were used. McCutchan (2001) for the isolation of grass pea protoplasts, from shoot tips and young leaves, as well as cell suspensions used a mixture containing four different enzymes (1\% Cellulysin, 0.5\% Driselase, $0.5 \%$ Pectinase and 0.1\% Pectolyase Y23). On the other hand, Durieu and Ochatt (2000) isolated protoplasts from an embryonic shoot axis using a mixture of 4\% Cellulase Onozuka R10, 3\% Macerozyme and 0.2\% Pectolyase Y-23. In the present experiments, the best protoplasts isolation efficiency reached $11.5 \times 10^{6}$ protoplasts /g fresh weight) and was much higher than the results obtained by McCutchan (2001) $-3 \times 10^{6}$ protoplasts/g f.w., as well as Durieu and Ochatt (2000) $-2 \times 10^{6}$ protoplasts /g f.w. The process of protoplast isolation is an important step in the procedure of plant regeneration from protoplast culture. It induces stress that affects a subsequent response of protoplasts to cult- 
Table 4. Protoplast morphology changes (\%) on subsequent days of culture in different media

\begin{tabular}{|c|c|c|c|c|c|c|c|c|c|c|c|c|c|c|c|c|c|c|}
\hline \multirow{3}{*}{ M } & \multicolumn{18}{|c|}{ Day of culture } \\
\hline & \multicolumn{3}{|c|}{1} & \multicolumn{6}{|c|}{5} & \multicolumn{5}{|c|}{10} & \multicolumn{4}{|c|}{15} \\
\hline & $\mathrm{S}^{*}$ & $\mathrm{D}$ & B & $\mathrm{S}$ & $\mathrm{D}$ & $\mathrm{E}$ & $\mathrm{B}$ & $\mathrm{O}$ & $\mathrm{SN}$ & $\mathrm{S}$ & $\mathrm{D}$ & $\mathrm{E}$ & B & $\mathrm{O}$ & $S$ & $\mathrm{D}$ & $\mathrm{B}$ & $\mathrm{O}$ \\
\hline K1 & $5.4 \mathrm{f}$ & $94.6 \mathrm{e}$ & $0 \mathrm{~b}$ & $0 \mathrm{e}$ & $100 \mathrm{~g}$ & $0 \mathrm{e}$ & $0 \mathrm{~d}$ & $0 \mathrm{f}$ & $0 \mathrm{c}$ & $0 \mathrm{e}$ & $100 \mathrm{~g}$ & $0 \mathrm{~d}$ & $0 \mathrm{~b}$ & $0 \mathrm{e}$ & $0 \mathrm{~b}$ & $100 \mathrm{~b}$ & $0 \mathrm{~b}$ & $0 \mathrm{~b}$ \\
\hline $\mathrm{K} 2$ & $3.4 \mathrm{f}$ & $96.6 \mathrm{e}$ & $0 \mathrm{~b}$ & $0 \mathrm{e}$ & $100 \mathrm{~g}$ & $0 \mathrm{e}$ & $0 \mathrm{~d}$ & $0 \mathrm{f}$ & $0 \mathrm{c}$ & $0 \mathrm{e}$ & $100 \mathrm{~g}$ & $0 \mathrm{~d}$ & $0 \mathrm{~b}$ & $0 \mathrm{e}$ & $0 \mathrm{~b}$ & $100 \mathrm{~b}$ & $0 \mathrm{~b}$ & $0 \mathrm{~b}$ \\
\hline $\mathrm{B} 1$ & $54.1 \mathrm{bc}$ & $51 \mathrm{bc}$ & $0 \mathrm{~b}$ & $7.8 \mathrm{~cd}$ & $75.9 \mathrm{~d}$ & $9.7 \mathrm{a}$ & $4.5 \mathrm{~b}$ & $1.1 \mathrm{e}$ & $1.1 \mathrm{a}$ & $0 \mathrm{e}$ & 94.6 ef & $1.0 \mathrm{~cd}$ & $3.9 \mathrm{~b}$ & 0.8 cde & $0 \mathrm{~b}$ & $100 \mathrm{~b}$ & $0 \mathrm{~b}$ & $0 \mathrm{~b}$ \\
\hline B2 & $28.8 \mathrm{e}$ & $72.2 \mathrm{~d}$ & $0 \mathrm{~b}$ & $3.0 \mathrm{de}$ & $88.3 \mathrm{f}$ & $2.2 \mathrm{~cd}$ & $2.9 \mathrm{bc}$ & $2.2 \mathrm{~d}$ & $1.4 \mathrm{a}$ & $0 \mathrm{e}$ & $100 \mathrm{~g}$ & $0 \mathrm{~d}$ & $0 \mathrm{~b}$ & $0 \mathrm{e}$ & $0 \mathrm{~b}$ & $100 \mathrm{~b}$ & $0 \mathrm{~b}$ & $0 \mathrm{~b}$ \\
\hline B3 & $52.7 \mathrm{c}$ & $47.3 \mathrm{bc}$ & $0 \mathrm{~b}$ & $4.1 \mathrm{de}$ & $79.5 \mathrm{de}$ & $0.8 \mathrm{de}$ & $10.7 \mathrm{a}$ & $4.9 \mathrm{c}$ & $0 \mathrm{c}$ & $1.9 \mathrm{de}$ & $87.6 \mathrm{~d}$ & $5.7 \mathrm{a}$ & $3.8 \mathrm{~b}$ & $1.0 \mathrm{~cd}$ & $0 \mathrm{~b}$ & $100 \mathrm{~b}$ & $0 \mathrm{~b}$ & $0 \mathrm{~b}$ \\
\hline B4 & $65.1 \mathrm{a}$ & $34.9 \mathrm{a}$ & $0 \mathrm{~b}$ & $33.7 \mathrm{a}$ & $40.5 \mathrm{a}$ & $4.4 \mathrm{bc}$ & $12.5 \mathrm{a}$ & $8.5 \mathrm{a}$ & $0.4 \mathrm{~b}$ & $6.4 \mathrm{c}$ & $67.7 \mathrm{a}$ & $5.4 \mathrm{ab}$ & $18 \mathrm{a}$ & $2.0 \mathrm{bc}$ & $0.5 \mathrm{a}$ & 89.5 a & $8.4 \mathrm{a}$ & $0.4 \mathrm{a}$ \\
\hline B5 & $0 \mathrm{f}$ & $100 \mathrm{e}$ & $0 \mathrm{~b}$ & $0 \mathrm{e}$ & $100 \mathrm{~g}$ & $0 \mathrm{e}$ & $0 \mathrm{~d}$ & $0 \mathrm{f}$ & $0 \mathrm{c}$ & $0 \mathrm{e}$ & $100 \mathrm{~g}$ & $0 \mathrm{~d}$ & $0 \mathrm{~b}$ & $0 \mathrm{e}$ & $0 \mathrm{~b}$ & $100 \mathrm{~b}$ & $0 \mathrm{~b}$ & $0 \mathrm{~b}$ \\
\hline B6 & $0 \mathrm{f}$ & $100 \mathrm{e}$ & $0 \mathrm{~b}$ & $0 \mathrm{e}$ & $100 \mathrm{~g}$ & $0 \mathrm{e}$ & $0 \mathrm{~d}$ & $0 \mathrm{f}$ & $0 \mathrm{c}$ & $0 \mathrm{e}$ & $100 \mathrm{~g}$ & $0 \mathrm{~d}$ & $0 \mathrm{~b}$ & $0 \mathrm{e}$ & $0 \mathrm{~b}$ & $100 \mathrm{~b}$ & $0 \mathrm{~b}$ & $0 \mathrm{~b}$ \\
\hline B7 & $40.1 \mathrm{~d}$ & $56.9 \mathrm{c}$ & $2.0 \mathrm{a}$ & $6.4 \mathrm{cde}$ & 84.5 ef & $3.3 \mathrm{c}$ & $4.5 \mathrm{~b}$ & $1.3 \mathrm{e}$ & $0 \mathrm{c}$ & $1.5 \mathrm{de}$ & $98.6 \mathrm{fg}$ & $0 \mathrm{~d}$ & $0 \mathrm{~b}$ & $0 \mathrm{e}$ & $0 \mathrm{~b}$ & $100 \mathrm{~b}$ & $0 \mathrm{~b}$ & $0 \mathrm{~b}$ \\
\hline B8 & $55.3 \mathrm{abc}$ & $44.3 \mathrm{ab}$ & $0.3 \mathrm{~b}$ & $12.3 \mathrm{c}$ & $77.9 \mathrm{~d}$ & $6.9 \mathrm{~b}$ & $1.7 \mathrm{~cd}$ & $1.3 \mathrm{e}$ & $0 \mathrm{c}$ & $3.8 \mathrm{~cd}$ & $92.2 \mathrm{de}$ & $2.7 \mathrm{bc}$ & $1.0 \mathrm{~b}$ & $0.5 \mathrm{de}$ & $0 \mathrm{~b}$ & $100 \mathrm{~b}$ & $0 \mathrm{~b}$ & $0 \mathrm{~b}$ \\
\hline B9 & $0 \mathrm{f}$ & $100 \mathrm{e}$ & $0 \mathrm{~b}$ & $0 \mathrm{e}$ & $100 \mathrm{~g}$ & $0 \mathrm{e}$ & $0 \mathrm{~d}$ & $0 \mathrm{f}$ & $0 \mathrm{c}$ & $0 \mathrm{e}$ & $100 \mathrm{~g}$ & $0 \mathrm{~d}$ & $0 \mathrm{~b}$ & $0 \mathrm{e}$ & $0 \mathrm{~b}$ & $100 \mathrm{~b}$ & $0 \mathrm{~b}$ & $0 \mathrm{~b}$ \\
\hline B10 & $3.7 \mathrm{f}$ & $96.1 \mathrm{e}$ & $0 \mathrm{~b}$ & $0 \mathrm{e}$ & $100 \mathrm{~g}$ & $0 \mathrm{e}$ & $0 \mathrm{~d}$ & $0 \mathrm{f}$ & $0 \mathrm{c}$ & $0 \mathrm{e}$ & $100 \mathrm{~g}$ & $0 \mathrm{~d}$ & $0 \mathrm{~b}$ & $0 \mathrm{e}$ & $0 \mathrm{~b}$ & $100 \mathrm{~b}$ & $0 \mathrm{~b}$ & $0 \mathrm{~b}$ \\
\hline B11 & $56.9 \mathrm{abc}$ & $43.1 \mathrm{ab}$ & $0 \mathrm{~b}$ & $36.2 \mathrm{a}$ & $63.2 \mathrm{~b}$ & $0 \mathrm{e}$ & $0 \mathrm{~d}$ & 0.7 ef & $0 \mathrm{c}$ & $21.5 \mathrm{a}$ & $76.0 \mathrm{~b}$ & $0 \mathrm{~d}$ & $0 \mathrm{~b}$ & $2.5 \mathrm{~b}$ & $0 \mathrm{~b}$ & $100 \mathrm{~b}$ & $0 \mathrm{~b}$ & $0 \mathrm{~b}$ \\
\hline B12 & $62.0 \mathrm{ab}$ & $38.0 \mathrm{a}$ & $0 \mathrm{~b}$ & $23.7 \mathrm{~b}$ & $67.8 \mathrm{c}$ & $2.5 \mathrm{~cd}$ & $0 \mathrm{~d}$ & $5.9 \mathrm{~b}$ & $0 \mathrm{c}$ & $10.1 \mathrm{~b}$ & $80.8 \mathrm{c}$ & $1.0 \mathrm{~cd}$ & $0 \mathrm{~b}$ & $8.2 \mathrm{a}$ & $0 \mathrm{~b}$ & $100 \mathrm{~b}$ & $0 \mathrm{~b}$ & $0 \mathrm{~b}$ \\
\hline
\end{tabular}

* S - spherical; D - degenerating; E - enlarged; B - budding; O - oval; SN - snowmen-like protoplasts

Means (within one protoplast type and time of observation) with the same letter are not significantly different 


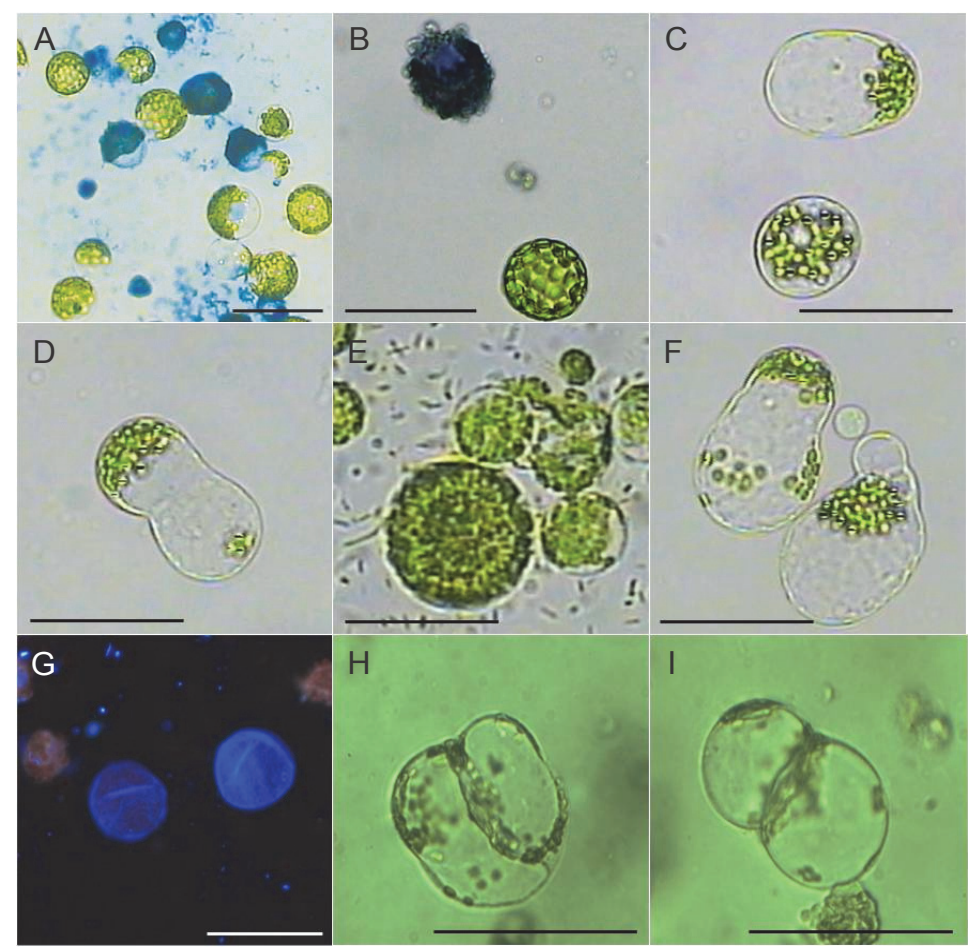

Fig. 1. Protoplasts of grass pea A-B) viability assessment of freshly isolated protoplasts (blue - non-viable protoplasts); C-F) protoplast morphology changes C) oval, D) snowmen-like, E) enlarged, F) budding protoplasts; G) visualization of reconstructed cell wall after 24 hours of cultivation; H-I) single cell division in agarose-droplet culture. Bar - $50 \mu \mathrm{m}$

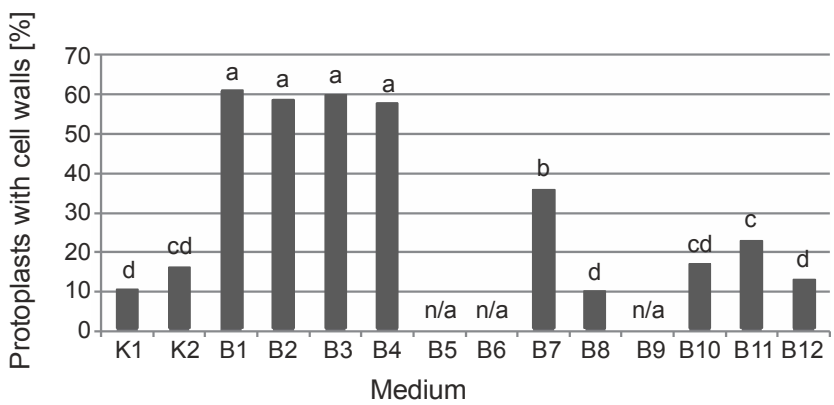

Fig. 2. Percentage of protoplasts with regenerated cell walls after 24 hours in different media; means with the same letter are not significantly different

ture conditions (Papadakis et al., 2001; Papadakis and Roubelakis-Angelaskis, 2002). The selection of a specific enzyme mixture influences not only the number of released protoplasts, but also their further morphogenic reactions in culture. Ochatt et al. (2000) observed that the application of an enzyme mixture different from that most suitable for a particular pea genotype resulted in an almost total lack of protoplast divisions.

In the present study, material incubated for 3-4 hours gave more viable protoplasts, although it gave a lower protoplast yield than during a prolonged incubation time. A short digestion period also reduced the yield of broad bean protoplasts, but its extension to over 16 hours decreased protoplast viability (Tegeder et al., 1995). Despite these findings, we decided to use overnight incubation and the ELII solution to isolate protoplasts for culture studies. This decision was motivated by the observation that, despite higher protoplast viability immediately after a short rather than overnight incubation, protoplasts from a short incubation degenerated much faster on subsequent days of culture. This most likely resulted from mechanical damage generated during shaking. The overnight incubation procedure has also been preferred in numerous studies on the protoplast culture of legumes (Puonti-Kaerlas and Eriksson, 1988; Rozwadowski et al., 1990; Tegeder et al., 1996; Durieu and Ochatt, 2000; Ochatt et al., 2000; McCutchan, 2001). The highest viability of grass pea protoplast directly after isolation was approx. 86\%, which was similar to the results obtained by Durieu and Ochatt (2000).

Protoplasts originating from different species and even from various tissues of the same plant vary in their requirements for culture conditions, especially with regards to the medium composition. The optimal composi- 
tion needs to be established experimentally (Davey et al., 2005). Between the compared two basal media $\left(\mathrm{B}_{5}\right.$ and $\mathrm{KM}$ ), $\mathrm{KM}$ proved to be ineffective for the culture of grass pea mesophyll protoplasts. Similarly, McCutchan (2001) noted no reaction of grass pea protoplasts to this medium. On the other hand, Durieu and Ochatt (2000) obtained the highest frequency of divisions leading to microcalli formation on a KP medium, i.e. a KM medium containing $0.1 \mathrm{mg} / \mathrm{l}$ of $2,4-\mathrm{D}, 0.2 \mathrm{mg} / \mathrm{l}$ zeatin and $1 \mathrm{mg} / \mathrm{l}$ NAA. In our study, better results - extended protoplast viability - were recorded on a modified $B_{5}$ medium. A modified $\mathrm{B}_{5}$ medium also stimulated divisions of $L$. odoratus protoplasts (Razdan et al., 1980). The supplementation of media with substances having a positive effect on different plant species protoplast cultures Pluronic F-68, acetylsalicylic acid (Carswell et al., 1989; Anthony et al., 1994) - did not stimulate grass pea protoplasts to divide. Instead, the longest viability of protoplasts was observed in media enriched with chitosan, which is a rather new compound tested in tissue culture systems (Uddin et al., 2004; Smith et al., 2006; Uthairatanakij et al., 2007; Limpanavech et al., 2008). The immobilization of protoplasts using agarose or sodium alginate has a beneficial effect on the induction of protoplast division, development of cell colonies and callus formation in many plant species (Shilito et al., 1983; Pati et al., 2005; Pati et al., 2008). Agarose embedding also caused a significant enhancement of the division rate in recalcitrant yellow lupine protoplasts (Wiszniewska and Pindel, 2009). However, in the described grass pea culture only single, sporadic divisions were observed in an agarose-droplet culture in B4 medium.

Up to $18 \%$ of grass pea protoplasts underwent "budding" in the established cultures. An incomplete or weak regeneration of the cell wall is believed to be the main reason for this process (Horine and Ruesink, 1972; Meyer and Abel, 1975; Firoozabady and DeBoer, 1986). The increasing frequency of "budding" was also attributed to the excessive protoplast density (Russell McCown, 1988) and a drastic pH decrease in the medium (Lehminger-Mertens and Jacobsen, 1989). In turn, Babaoglu (2000) observed a more frequent "budding" of enlarged Lupinus mutabilis protoplasts. After 24 hours, from $10 \%$ to $60 \%$ of "Derek" grass pea protoplasts created a new cell wall depending on the medium composition. In contrast, after two days of culture only $7-9 \%$ of mesophyll yellow lupine protoplasts had visible cell walls
(Wiszniewska and Pindel, 2013). However, the presence of the previously mentioned "budding" points indirectly to irregularities in the reconstruction of cell walls, which can affect the mitotic activity of protoplasts. Total cell wall regeneration determines the cell mitotic activity (Nagata and Takebe, 1970; Tylicki et al., 2001).

\section{Conclusions}

A rapid decline in protoplast viability, together with disturbances in cell wall rebuilding are the main reasons for impaired development of grass pea protoplast cultures. Nevertheless, the first protoplast division observed in an agarose solidified medium indicates that immobilization is necessary to stimulate further culture growth. The present results confirm that grass pea protoplasts are difficult to study. However, the high utility potential of this species and the prospect of achieving somatic hybridization that may induce a new genetic variability encourages attempts to search for new methods enabling further development of this in vitro technique.

\section{Acknowledgements}

This study was financially supported by the Polish Ministry of Science and Higher Education (DS 3500).

\section{References}

Anthony P., Davey M.R., Power J.B., Washington C., Lowe K.C. (1994) Synergistic enhancement of protoplast growth by oxygenated perfluorocarbon and Pluronic F-68. Plant Cell Rep. 13(5): 251-255.

Atanassov A., Brown D.C.W. (1984) Plant regeneration from suspension culture and mesophyll protoplasts of Medicago sativa L. Plant Cell Tiss. Cult. 3(2): 149-162.

Babaoĝlu M. (2000) Protoplast isolation in lupin (Lupinus mutabilis Sweet): Determination of optimum explant sources and isolation conditions. Turk. J. Bot. 24: 177-185.

Blackhall N.W., Davey M.R., Power J.B. (1994) Isolation, culture, and regeneration of protoplast. [in:] Plant Cell Culture. A Practical Approach. R.A. Dixon, R.A. Gonzales (eds.), Oxford University Press, New York: 27-38.

Campbell C.G., Mehra R.B., Agrawal S.K., Chen Y.Z., Abd El Moneim A.M., Khawaja H.I.T., Yadov C.R., Tay J.U., Araya W.A. (1994) Current status and future strategy in breeding grasspea (Lathyrus sativus ). Euphytica 73: 167175.

Campbell C.G. (1997) Grass pea. Lathyrus sativus L. Promoting the conservation and use of underutilized and neglected crops. 18. Institute of Plant Genetics and Crop Plant Research. Gatersleben International Plant Genetic Resources Institute, Rome, Italy. 
Carswell G.K., Johnson C.M., Shillito R.D., Harms C.T. (1989) O-acetyl-salicylic acid promotes colony formation from protoplasts of an elite maize inbred. Plant Cell Rep. 8(5): 282-284.

Castelblanque L., García-Sogo B., Pineda B., Moreno V. (2010) Efficient plant regeneration from protoplasts of Kalanchoe blossfeldiana via organogenesis. Plant Cell Tiss. Org. Cult. 100(1): 107-112.

Davey M.R., Anthony P., Power J.B., Lowe K.C. (2005) Plant protoplasts: status and biotechnological perspectives. Biot. Adv. 23(2): 131-171.

Dhir S.K., Dhir S., Widholm J.M. (1992) Regeneration of fertile plants from protoplasts of soybean (Glycine max L. Merr.): genotypic differences in culture response. Plant Cell Rep. 11(5-6): 285-289.

Durieu P., Ochatt S.J. (2000) Efficient intergeneric fusion of pea (Pisum sativum L.) and grass pea (Lathyrus sativus L.) protoplasts. J. Exp. Bot. 51(348): 1237-1242.

Firoozabady E., DeBoer D.L. (1986) Isolation, culture, and cell division in cotyledon protoplasts of cotton (Gossypium hirsutum and G. barbadense). Plant Cell Rep. 5: 127131.

Frearson E.M., Power J.B., Cocking E.C. (1973) The isolation, culture and regeneration of Petunia leaf protoplasts. Dev. Biol. 33: 130-137.

Gaff D.F., Okong'o-Ogola O. (1971) The use of non-permeating pigments for testing the survival of cells. J. Exp. Bot. 22(3): 756-758.

Gamborg O.L., Miller R., Ojima K. (1968) Nutrient requirements of suspension cultures of soybean root cells. Exp. Cell Res. 50(1): 151-158.

Gill R., Eapen S., Rao P.S. (1987) Callus induction from protoplasts of $V$. ungiuculata, $V$. sublobata and $V$. mungo. Theor. Appl. Genet. 74: 100-103.

Horine R.K., Ruesink A.W. (1972) Cell wall regeneration around protoplasts isolated from Convolvulus tissue culture. Plant Physiol. 50: 438-445.

Hu Q., Andersen S.B., Hansen L.N. (1999) Plant regeneration capacity of mesophyll protoplasts from Brassica napus and related species. Plant Cell Tiss. Org. Cult. 59(3): 189-196.

Kao K.N., Michayluk M. R. (1975) Nutritional requirements for growth of Vicia hajastana cells and protoplasts at a very low population density in liquid media. Planta 126(2): 105-110.

Kowalski B., Terry F.J., Herrera L., Peňalver D.A. (2006) Application of soluble chitosan in vitro and in the greenhouse to increase yield and seed quality of potato minitubers. J. Potato Res. 49(3): 167-176.

Lal R., Lal S. (2000) Crop Improvement Utilizing Biotechnology. CRS Press, Boca Raton: 117-128.

Lehminger-Mertens R., Jacobsen H. (1989) Protoplast regeneration and organogenesis from pea protoplasts. In Vitro Cell. Dev. Biol. 25(6): 571-574.

Limpanavech P., Chaiyasuta S., Vongpromek R., Pichyangkura R., Khunwasi, C., Chadchawan S., Lotrakul P., Bunjongrat R., Chaidee A., Bangyeekhun T. (2008) Chitosan effects on floral production, gene expression, and anatomical changes in the Dendrobium orchid. Sci. Hortic. 116: 65-72.

McCutchan J.S. (2001) Transferring ascochyta blight resistance from Lathyrus sp. into field pea (Pisum sativum L.) via protoplast fusion (somatic hybridisation). $\mathrm{PhD}$ Thesis.

Meyer Y., Abel W.O. (1975) Budding and cleavage division of tobacco mesophyll protoplasts in relation to pseudo-wall and wall formation. Planta 125: 1-13.

Murashige T., Skoog F. (1962) A revised medium for rapid growth and bio assays with tobacco tissue cultures. Physiol. Plant. 15(3): 473-497.

Nagata T., Takebe I. (1970) Cell wall regeneration and cell division in isolated tobacco mesophyll protoplasts. Planta 92: 301-308.

Nagata T., Takebe I. (1971) Plating of isolated tobacco mesophyll protoplasts on agar medium. Planta 99(1): 12-20.

Ochatt S.J., Mousset-Děclas C., Rancillac C.M. (2000) Fertile pea plants regenerate from protoplasts when calluses have not undergone endoreduplication. Plant Sci. 156: 177-183.

Papadakis A.K., Roubelakis-Angelakis K.A. (2002) Oxidative stress could be responsible for the recalcitrance of plant protoplasts. Plant Physiol. Biochem. 40: 549-559.

Papadakis A.K., Siminis C.I., Roubelakis-Angelakis K.A. (2001) Reduced activity of antioxidant machinery is correlated with suppression of totipotency in plant protoplasts. Plant Physiol. 126: 434-444.

Pati P.K., Sharma M., Ahuja P.S. (2005) Extra thin alginate film: an efficient technique for protoplast culture. Protoplasma 226(3-4): 217-221.

Pati P.K., Sharma M., Ahuja P.S. (2008) Rose protoplast isolation and culture and heterokaryon selection by immobilization in extra thin alginate film. Protoplasma 233(1-2): 165-171.

Puonti-Kaerlas J., Eriksson T. (1988) Improved protoplast culture and regeneration of shoots in pea (Pisum sativum L.). Plant Cell Rep. 7: 242-245.

Razdan M.K. (1980) Callus regeneration from mesophyll protoplasts of sweet pea (Lathyrus odoratus L.). Z. Pflanzenphysiol. 96: 181-183.

Rozwadowski K.L., Saxena P.K., King J. (1990) Isolation and culture of Lens culinaris Medik. cV. Eston epicotyl protoplasts to calli. Plant Cell Tiss. Org. Cult. 20: 75-79.

Russell J.A., McCown B.H. (1988) Recovery of plants from leaf protoplasts of hybrid-poplar and aspen clones. Plant Cell Rep. 7: 59-62.

Rybczyński J.J. (2001) Lupin biotechnology(in Polish). Zesz. Nauk. AR we Wrocławiu, Rolnictwo 82 (427): 93-114.

Rybiński W. (2003) Mutagenesis as a tool for improvement of traits in grass pea (Lathyrus sativus L.). Lathyrus Lathyrism Newsl. 3: 27-31.

Shepard J.F., Totren R.F. (1977) Mesophyll cell protoplasts of potato. Isolation, proliferation and plant regeneration. Plant Physiol. 60: 313-316.

Shillito R.D., Paszkowski J., Potrykus I. (1983) Agarose plating and a bead type culture technique enable and stimulate 
development of protoplast-derived colonies in a number of plant species. Plant Cell Rep. 2(5): 244-247.

Sinha A., Wetten A.C., Caligari P.D.S. (2003) Effect of biotic factors on the isolation of Lupinus albus protoplasts. Aust. J. Bot. 51: 103-109.

Takebe I., Labib G., Melchers G. (1971) Regeneration of whole plants from isolated mesophyll protoplasts of tobacco. Naturwissenschaften 58(6): 318-320.

Tegeder M., Gebhardt G., Schieder O., Piekardt T. (1995) Thidiazuron-induced plant regeneration from protoplasts of Vicia faba cv. Mythos. Plant Cell Rep. 15: 164-169.

Tegeder M., Kohn H., Nibbe M., Schiedera O., Pickardt T. (1996) Plant regeneration from protoplasts of Vicia narbonensis via somatic embryogenesis and shoot organogenesis. Plant Cell Rep. 16: 22-25.

Thomas T.D. (2009) Isolation, callus formation and plantlet regeneration from mesophyll protoplasts of Tylophora indica (Burm. f.) Merrill: an important medicinal plant. In Vitro Cell Dev. Biol. Plant. 45(5): 591-598.

Tylicki A., Burza W., Malepszy S., Kuraś M. (2001) Regeneration of the cell wall by isolated protoplasts of Solanum lycopesicoides Dun. is a selective process. Biol. Bull. Poznań 38(1): 97-101.
Uddin A.F.M.J., Hashimoto F., Shimizu K., Sakata Y. (2004) Monosaccharides and chitosan sensing in bud growth and petal pigmentation in Eustoma grandiflorum (Raf.)Shinn. Sci. Hort. 100: 127-138.

Uthairatanakij A., Teixeira da Silva J.A., Obsuwan K. (2007) Chitosan for improving orchid production and quality. Orchid Sci. Biotech. 1: 1-5.

Vaz Patto M.C., Skiba B., Pang E.C.K., Ochatt S.J., Lambein F., Rubiales D. (2006) Lathyrus Improvement for resistance against biotic and abiotic stresses: From classical breeding to marker assisted selection. Euphytica 147: 133147.

Wiszniewska A., Pindel A. (2013) Explant-dependent receptivity to isolation and a cellwall resynthesis in protoplast culture of recalcitrant yellow lupin. J. Centr. Europ. Agricult. 14(1): 143-156.

Wiszniewska A., Pindel A. (2009) Improvement in Lupinus luteus (Fabaceae) protoplast culture-stimulatory effect of agarose embedding and chemical nursing on protoplast divisions. Aust. J. Bot. 57(6): 502-511. 